\title{
Separated Parents Reproducing and Undoing Gender through Defining Legitimate Uses of Child Support
}

Abstract:

The use of child support is a politically and personally contested issue and a policy challenge across developed countries. This offers an opportunity to identify family practices and relationships through which hegemonic masculinity and socially valued femininities are reproduced and challenged. We present data from interviews with 28 fathers and 30 mothers to argue that when people discuss how child support is or should be spent, they are managing gendered parenting identities. Most fathers defined child support as "special money." This position buttresses the hegemonic masculine characteristics of authority and breadwinning, discursively degenders the care of children, and challenges mothers' conformity to feminine and good mothering ideals. A minority of fathers presented an alternative definition of child support and fathering that underplays the relevance of money and values mothers' and fathers' care and financial contributions. Mothers' accounts of using child support emphasized their financial authority and child-centered consumption in ways that both challenges and reproduces socially valued femininity. We conclude that definitions of how child support should be used reproduce relationships of dominance and subordination that constitute the gender order. 
In the context of relationship breakdown and divorce, child support has become a personal and policy challenge. The legal requirements differ across jurisdictions, but parents often experience child support as an intrusion into family life (Crowley 2008; Edin and Lien 1997), which may exacerbate tensions between parents (Patrick, Cook, and McKenzie 2008). Non-payment of child support decreases the household income of resident parents, usually single mothers, and increases government spending on enforcement activities and welfare support (Skinner and Main 2013). Responding to these issues, research on child support has examined its transfer and impact as a financial resource (Cancian and Meyer 2005; Skinner and Main 2013) or emphasized the meanings of its payment and receipt (Bradshaw et al. 1999; Natalier 2012a; Natalier and Hewitt 2010). There has been no extended focus on expectations of how child support should be allocated and spent (Bradshaw et al. 1999; Simpson 1998). In this article, we explore mothers' and fathers' definitions of "legitimate" uses of child support, an issue that speaks to a widespread and contested element of post-separation parenting in which money, care, and gendered parenting identities intersect.

Questions about the allocation and spending of child support are political. Fathers' rights groups argue that amounts of child support do not reflect the direct costs of raising children, narrowly defined as child-specific items and services (Boyd 2003; Cook and Natalier 2013; Crowley 2008). These groups claim that fathers pay too much child support and mothers spend the money for their own expenses rather than on their children (Boyd 2003; Crowley 2008). These claims can be translated into legislative changes that potentially limit the financial resources available to mothers and children (Boyd 2003; Fehlberg and Maclean 2009). For example, in Australia, where this study was conducted, new legislative provisions have enabled fathers to direct up to 30 percent of their child support payment to specific expenditures (e.g., 
school fees), irrespective of the mother's consent (Fehlberg and Behrens 2008). Thus, defining legitimate uses of child support can shape post-separation policies with real implications for the finances of separated parents.

The legitimate uses of child support are also important for gender theory. Our focus on post-separation parenting allows an engagement with the project of capturing the contexts and interactions in which gender difference is reproduced or reduced (Deutsch 2007). Because gender is contextually accomplished, there are possibilities of continuity and change in the characteristics of masculinities and femininities and relations of domination and subordination that are central to the gender order (Connell and Messerschmidt 2005). In post-separation parenting, key elements of hegemonic masculinity and socially valued femininities are unavailable or contested at local (interactional) and regional (state and structural) levels (Connell and Messerschmidt 2005; Deutsch 2007). Parenting occurs outside of normative heterosexual marriage, and the gendered practices of care and financial provision are often re-negotiated, making it a valuable and interesting context for examining the existence and gender-disruptive potential of alternative masculinities and femininities.

Our analysis draws on Zelizer's (1994) conceptualization of special money. Zelizer (1994) notes that people assign different meanings to, and separate uses for, particular monies a process she terms the social "earmarking" of money. Through differentiation, currency is transformed into "special money", a categorization limiting how money can be legitimately claimed, allocated, and spent. We argue that a gendered definition of child support as special money facilitates the reproduction and adjustment of gendered parenting identities. Almost all of the fathers in the study described child support as "special money". This reinforced the importance of their money and care in their children's lives, and implied equivalence between 
their own and their former partner's contributions. Defining child support as special money also allowed fathers to question the legitimacy of their former partner's spending and mothering, based on an alignment of mothering with traditionally feminine characteristics of nurturance and financial dependency. Only three fathers presented a different interpretation of child support, rejecting the "specialness" of child support and their authority to define legitimate spending and mothering practices. Claims about similarities between mothers' and fathers' contributions suggest a de-gendering of care in post-separation parenting. However, most fathers' emphasis on the importance and discretionary nature of their child support contributions was a strategy of control - a key element of hegemonic masculinity. Mothers' descriptions of using child support linked finances with authority and independence in ways that suggest alternatively gendered connections between motherhood and money. However, they contextualized their use of child support in their broader work of caring for children, presenting identities that conformed to the

feminine ideal of child-centered maternal responsibility. We conclude that in the context of postseparation parenting, special money is not only a flashpoint of conflict but a tool to reproduce dominance and subordination between men and women, even when specific parenting acts, such as child care, are subject to discourses that undo gender.

\section{The Financial and Care Dimensions of Post-separation Fathering and Mothering}

Control and authority are central to hegemonic masculinity (Johnson 2005). They are evident in the position of breadwinning as a defining element of successful manhood and fatherhood (Randles 2013). The dynamics of men's power over household money vary across structural and cultural positions, but men's right to "have a say" on how money is spent is a consistent finding (Kenney 2006). When parents live apart, control is implicit in the 
discretionary and sporadic nature of many fathers' financial contributions (Edin and Lein 1997;

Edin and Nelson 2013). Non-residential Fathers use child support to demonstrate their identities as good fathers (Edin and Nelson 2013; Natalier and Hewitt 2010 ) - and, implicitly, good men. The expectation of control sits in tension with men's experiences of paying child support. Child support is an imposed obligation (Crowley 2008), and residential mothers have situational power over how the money is spent (Smart and Neale 1999). Fathers may fear the meanings of their financial contributions are lost because their child support payments are invisible when incorporated into a mother's household budget (Bradshaw et al. 1999). Thus, fatherhood and masculinity are expressed through paying child support but are mediated by law and mothers' use of the money.

Increasingly, hegemonic masculinities incorporate relational elements of fathering. Masculine care of children centers on play, discipline, and role modeling (Weiss 2000). It informs fathers' rights groups' claims for greater acknowledgment of the importance of men's gendered contributions to children's well-being (Gavanas 2004). Masculine care is often discretionary (Edin and Nelson 2013), supported by mothers' care activities (Elizabeth, Gavey, and Tomie 2012b), and shaped by the imperatives of paid work (Lacroix 2006; Shows and Gerstel 2009). It is also classed and raced (Randles 2013; Shows and Gerstel 2009). For example, in the U.S., low-income men's care for children is institutionalized in welfare and education programs that emphasize "responsible" or "involved" fathering, with the aim of developing masculine identities that reduce welfare dependence (Randles 2013).

Good mothers orient their lives to the care of their children (Hays 1996). Their care is understood as an expression of intrinsic feminine qualities of nurturance, gentleness, and responsiveness to others' needs (Ruddick 1989). These qualities are enacted through providing 
for their children (Pugh 2009). Shopping is one component of budgeting, planning, and provisioning tasks that are largely invisible and taken for granted (Devault 1991; Elizabeth, Gavey, and Tolmie 2012a) because caring for others is understood as the natural orientation of women. Spending money therefore exposes mothers to the judgment of others. This is particularly so for single and low-income mothers, who do not conform to socially valued femininities, and are subject to discourses that problematize their mothering and spending (Casey 2003; McCormack 2005). Mothers are aware of this risk and work to emphasize the childcenteredness of their consumption practices (Casey 2003).

The expectation of mothering within marriage positions women in dependent relationships with men (Fraser and Gordon 1994). Women are, ideally, reliant on their husbands' earnings and acknowledge masculine authority when deciding how to spend money. However, emerging definitions of being a good mother include paid labor. Christopher (2012) describes "extensive mothering," a combination of paid labor and necessary delegation of care tasks, as an extension of intensive mothering. Other researchers have highlighted the ways in which class and race inform mothers' interpretation of paid work as a valuable part of mothering that benefits their children (Collins 2000; Johnston and Swanson 2006).

In the following analysis we use Zelizer's (1994) insights into "special money" to explore how child support is used to present fathering and mothering identities that align with and challenge hegemonic masculinity and socially valued femininities. Disputes arise when people have conflicting perspectives on their relationship, values, or interests, or when they have adopted different techniques for earmarking (Zelizer 1994). These tensions are particularly evident in fathers' expectations of how mothers should use child support. 


\section{CONTEXT AND METHODS}

The Australian Child Support Scheme (CSS) was introduced in 1989 to address high rates of poverty among children of separated mothers and the rising costs of mitigating this poverty (Fehlberg and Mclean 2009). The CSS has two central elements: the formula, which is a standardized calculation of the amount of money to be transferred between parents, and the Department of Human Services (Child Support) (DHSCS) (formerly the Child Support Agency [CSA]), which provides administrative support to calculate, transfer, and enforce payments.

Child support is administered through the DHSCS or by private agreement between parents. Approximately 1.5 million parents use the DHSCS to calculate and/or transfer child support (Child Support Agency 2010). Payments are most commonly transferred from fathers (87 percent of payers) to mothers (Child Support Agency 2010). Many DHSCS clients live on low incomes and receive welfare payments (Child Support Agency 2010). Between 5 and 20 percent of separated parents use private agreements (Smyth and Henman 2010), operating outside the DHSCS with no formal requirements as to amount, regularity, or processes by which money is transferred. The socio-economic characteristics of this group are unstudied.

For many Australian families, the CSS is an unavoidable element of parenting across households. Over one quarter of Australian children do not live with both biological parents, mostly due to relationship dissolution (Australian Bureau of Statistics 2012), and most of these children live in female-headed sole parent households (Australian Bureau of Statistics 2011). Child support is not part of an explicitly articulated approach governing welfare payments, and is not universally mandatory. Payers can recieve government benefits without a child support agreement. Payees can claim entitlements to government benefits (such as income support or rent relief) only when child support agreements are lodged with or administered by the DHSCS 
(Summerfield et al. 2010). As a result, most mothers seek child support and most fathers are required to pay.

In Australia, child support is a financial relationship between parents. In contrast to other countries, like the U.S. and New Zealand, the money is not paid to reimburse state expenditure on children (Birks 2011; Skinner and Davidson 2009). Failure to pay accrues a debt to the former partner, not the state. One quarter of payers have debts (Child Support Agency 2011), and payees report difficulties in enforcing payers' compliance (Natalier 2012b).

The most recent changes to the CSS were implemented between 2006 and 2008. These were informed by fathers' rights arguments that the CSS and family law generally advantaged mothers at the expense of fathers (Cook and Natalier 2013). These reforms changed the child support formula and increased payers' power to allocate payments for specific costs (Smyth and Henman 2010). The new formula reflects a marginal costs approach to calculating the expenses of raising children, that is, the cost of children is the difference between the amount necessary to meet household expenses without children and the costs accruing with children (Ellman 2004). Pre- and post-reform, the CSS has reflected the principles that both parents have a duty to financially support their children, and child support is paid to benefit children (Fehlberg and Maclean 2009).

Our research was informed by a constructivist-interpretivist paradigm, which perceives people as making sense of their worlds in interaction with others (Silverman 2001). We present data as participants' contextualized understandings of their practices and beliefs, and those they ascribed to their former partners. The information participants shared reflected interpretations developed at a particular point in the interview, their biographies, and the social and cultural contexts. 
We interviewed 58 separated parents: 28 fathers liable to pay child support and 30 mothers due to receive child support. We recruited participants using snowball sampling, flyers, and advertising aimed at separated parents' support groups. None of the participants had been partnered with each other. We collected data on current relationship status, although not systematically on relationship history. Our sample included parents of children born in marriage, those in de facto relationships, and those who were un-partnered. Twenty fathers were not living with a partner, one was cohabiting, and seven were married. Eighteen mothers were not living with a partner, four were cohabiting, and eight were married.

In the following discussion, dollar amounts refer to Australian dollars. Eight fathers had household incomes that placed them at or below the poverty line of $\$ 32,000$ per annum (28.5 percent of the sample compared to 18 percent of Australian men) (Australian Bureau of Statistics 2013). One quarter of fathers reported household incomes that placed them in the top 10 percent of Australian households. The rest reported incomes of between $\$ 45,000$ and $\$ 60,000$ (compared to the median household income of approximately $\$ 54,000$ when the study was conducted [Australian Bureau of Statistics 2008]). Nineteen fathers had DHSCS-supported agreements, four had private agreements, two did not pay child support, and one had child support deducted compulsorily from his wages. The average amount of child support paid was $\$ 73$ per week. Six fathers paid $\$ 5$, the minimum child support calculated by the formula at the time of the research, or less each week. Five fathers had approximately equal shared care of their children; of the remainder, most had regular contact (usually every second weekend), four had limited contact (for example, school holidays), and three had not seen their children for at least one year.

Twenty mothers reported incomes at or below the poverty line (67 percent of the sample compared to 20 percent of Australian women [Australian Bureau of Statistics 2013]). Two 
mothers (6.5 percent of the sample) had household incomes that placed them in the top 10 percent of Australian household incomes. The rest reported household incomes of between $\$ 38,000$ and $\$ 60,000$ per year. Twenty-three mothers had child support agreements administered through the DHSCS, five had private agreements, and two received payments compulsorily deducted from their former partner's wages. The average amount of child support received was $\$ 60$ per week. Ten mothers received $\$ 5$ or less child support each week. All, except one, were the primary carer of their children.

We used semi-structured interviews to generate data. The initial study investigated the impact of the payment and receipt of child support on housing (Natalier et al. 2008), but semistructured interviews allowed participants to discuss issues important to them. In this process people described how child support should be used. We manually coded transcripts, using a constant comparative method across and within the mothers and fathers samples. Our analysis was partially inductive, informed by existing literature and emergent themes.

Our findings should be interpreted with reference to the sample and study design. Data collection occurred between October 2006 and June 2007, prior to the reforms. The amount of some participants' liabilities and entitlements would be different now, but these changes were unlikely to have altered participants' understandings of legitimate uses of child support. Our sample included people from different socio-economic positions, child support arrangements, and post-separation experiences, but the sample was white and included only heterosexual parents. Masculinities and femininities and fathering and mothering alter with social positioning, so we might expect to find additional practices and meanings in a more diverse sample. Recruiting through support groups may have led to an over-sampling of people particularly distressed by their separations, shaping their interpretations of their circumstances and former 
partner's behavior. We present our discussion and conclusions in light of the aim of qualitative research: to generate nuanced and detailed understandings without making claims about the distribution of experiences across a population (Rice and Ezzy 1999).

\section{REPRODUCING AND UNDOING HEGEMONIC MASCULINITY AND SOCIALLY VALUED FEMININITY THROUGH DEFINING LEGITIMATE USES OF CHILD SUPPORT}

In this section we explore how fathers and mothers used child support to reinforce and challenge fathering and mothering, and masculine and feminine identities. We present the accounts of the majority of fathers, who defined child support as special money and claimed masculine control over money. We then discuss those fathers who did not expect child support to be earmarked and did not claim authority to determine its use. Finally, we describe how mothers' accounts of using child support emphasized the well-being of their children and their financial autonomy in ways that reproduced and challenged socially valued femininities.

\section{Fathers' Descriptions of Child Support as Special Money}

Most fathers described child support in ways that defined it as special money. Earmarking for child-specific costs was the only legitimate way former partners could designate child support, an expectation that reflected previous studies (Bradshaw et al. 1999; Simpson 1998). Bill (2 children; annual income $\$ 100,000$; annual child support paid $\$ 15,600$; cares for the children three nights a week) recited the child-specific goods and services nominated by many fathers: "The money should be exclusive for piano lessons, clothing, sports, subscriptions." When fathers expected child support to be used "exclusively" for such costs, they were claiming "their" money should be used to reflect their economic contributions to their children's lives in ways that aligned with the importance of breadwinning in hegemonic masculinity. 
The economic dimension of good fathering was important for fathers who saw themselves meaningfully contributing to their children's care. Bill, who emphasized caring for and caring about his children, followed his list of appropriate spending with an account of his response to his son's request for more money for clothes:

I said, "That maintenance [child support] pays for everything for you, Bob [nickname]. If I buy you a[nother] pair of sandshoes, that's at my discretion.

Everything else is paid for by your mother [from child support]."

Like other fathers in this study and in previous studies (Bradshaw et al. 1999; Natalier and Hewitt 2010; Simpson 1998) Bill was concerned that his contributions were invisible to his child. This invisibility implied that Bill failed to meet the financial dimensions of hegemonic masculinity. He countered this by referencing hegemonic ideals of breadwinning (he "pays for everything") and control over money. Given his definition of child support as special money, Bill's reference to his former partner spending the money was not an acknowledgement of her financial authority, but a reflection of her role as the executor of his child support priorities - an administrative function to his control (Volger, Lyonette, and Wiggins 2008).

Fathers' accounting reflected an intuitive, child-specific marginal costs approach to determining appropriate amounts and uses of child support. This is exemplified when Bill contrasted child-specific items with costs borne by both his former partner (who had a lower income and more care of the children) and himself:

...I think the basic difficulty is that she thinks that the $\$ 1,350$ should pay a portion of housing, fuel, vehicle expenses, and everything else. My argument is, well, they're things you would have whether there were children or not. 
The difference between expectations of earmarking and calculations of child-specific marginal costs underpinned many fathers' belief that their former partners spent the money inappropriately - concerns that echoed the claims of fathers' rights groups (Crowley 2008). Matt's comments (2 children; annual income $\$ 62,000$; annual child support paid $\$ 15,600$; cares for the children two nights each week) exemplified this:

I really have a lot of doubts that it's all going on the children. When we were married there was no way we were spending that. We couldn't. We didn't have $\$ 300$ to spend on the kids. It's as simple as that.

Similarly, Bill commented: “Personally, I can’t spend $\$ 1,350$ on two children in a month, for those things. I can't do that.” Personal experience informed calculations of appropriate amounts of child support. These calculations presented fathers' time and material contributions to their children's care, and the financial implications of those contributions, as equivalent to those of mothers. They downplayed the economic importance of the often invisible care tasks more commonly falling to mothers after separation (Elizabeth, Gavey, and Tolmie 2012b; Lacroix 2006) and the infrastructure costs and routine expenses that increase with children in the household. They elided mothers' financial contributions to meeting children's needs, the extent, value, and impact of their care work, and their disadvantaged position in the labor market. The fathers did not emphasize masculine care (Weiss 2000) and focused on the equivalence of mothers' and fathers' contributions in ways that suggest a de-gendering of care, post-separation.

Dissatisfaction with the lack of correspondence between payments and the costs of children was also evident among fathers who paid small amounts of child support. Ted (3 children; annual income $\$ 12,000$; annual child support paid $\$ 338$; cares for the children 2 days 
each month) queried his former wife's spending of "my child support," which was the minimum obligation for three children:

Ted: The fact is that I don't know how my child support payments are being used. When they are with me they still have needs that need to be dealt with and I need to provide them for them out of my pocket at that time.

Interviewer: So, food and transport costs and all those things?

Ted: Nappies and everything else. Because those don't seem to be supplied in the last two visits I've had. They're pretty costly.

Interviewer: They're very costly.

Ted: Yes, I would have thought my \$12.56 every fortnight was going towards that. I don't know what my child support goes to. Hopefully, towards my children.

Ted's circumstances conflicted with the ideals of marriage, breadwinning, and control central to hegemonic masculinity. Before separation he left his career to care for the children; at the time of the interview he received unemployment benefits and his former wife controlled his contact with the children. Ted claimed an identity as a father and a man through his orientation to the children's care - an orientation that was different from traditional masculine care ideals (Weiss 2000). He detailed his child-centered decisions (relocating to be near the children, renting an appropriate house) pursued at personal and financial cost. Ted's concern about a lack of nappies can be read as a means of contrasting his orientation to his children's needs with his former wife's failure to take responsibility for the children's hygiene and comfort - a critique that reflected claims throughout the interview that she was not child-centered, not a "good mother." 
Ted's questions about his former wife's use of child support were statements more about masculinity and femininity than the cost of nappies.

Care and money were used to enact a masculine identity even when fathers did not spend time with their children. Isaac ( 1 child; annual income $\$ 31,000$; annual child support paid $\$ 4,000$; no contact with the child) never saw his child. The lack of an ongoing relationship contradicted the care dimension of fathering ideals: "I don't see myself as a parent in that way anymore because I haven't done the parenting, which is about growing and being there." $\mathrm{He}$ presented his situation as a response to his former partner's "astonishingly bitter" behaviors, implying the issue was the result of his former partner's failure to conform to feminine ideals of gentleness and responsiveness to men's needs, rather than any failures on his part. Isaac's accounting echoed the dissatisfaction of other fathers:

My experience of raising a child is completely different to [former partner's] experience, so my figure is extremely low, hers is extremely high. And so I made a placatory gesture by offering that amount. ... It's far too high for what it costs to bring up a child. I know that, with my son [in another relationship].

Isaac emphasized control over money by presenting himself as exercising his discretion to pay ("I made a placatory gesture"). He linked his criticisms about child support to his former partner's materialism: the amounts he paid reflected not the child's needs but the mother's desires, implying her lack of child-centeredness. Like other fathers, Isaac drew on his experiences of care (in this case, a child with a new partner) to estimate the costs of children's care. Isaac's accounting also reflected his ideological commitment to simplicity, which became the basis of an imagined future that included caring for his child. This obligation reflected the role modeling traditionally part of masculine care of children (Weiss 2000): "My duty would be, 
I think, to present to her a philosophical and different form of care, alternatives.” These alternatives would counter the consumerism he believed characterized his former partner's spending (spending that reflected the practices and orientations of intensive mothering [Hays 1996]). Financial dimensions of fathering were central to Isaac's current fathering identity, but the possibility of emotional (if not physical) dimensions offered another point of connection between fathering and masculinity.

Three fathers did not define child support as special money. They viewed child support as appropriately integrated into their former partner's household budgets. Tom (1 child; annual income $\$ 52,000$; annual child support paid $\$ 0$; equal shared care), with his former partner's agreement, did not pay child support at the time of the interview. He remembered that when he had paid child support in the past he:

I had a lot of trust for her even though there were some aspects that I wasn't $100 \%$ with, and she made it clear to me that she would make sure that the money got to [child]. And you know, it may have freed her money up to do more that she wanted to do that I may not have approved of but it was almost irrelevant.

Tom recognized he had no authority to impose his definitions of the legitimate uses of child support, and did not judge his former partner as a good or bad mother on the basis of those definitions. Implicit within this relationship of trust, however, were expectations of the earmarking and child-centered spending of good mothering, even if Tom did not present these considerations as appropriate.

The fathers shared three characteristics that, taken together, distinguished them from the rest. First, they described their fathering primarily in terms of time spent caring for their children in ways that echoed traditionally feminine care activities. Bob ( 2 children; annual income 
$\$ 30,000$; annual child support paid $\$ 380$; contact with children limited to school holidays, with no overnight stays) described his orientation to care:

I'd love to have them as much as possible, like any parent. It's very hard to be away from your children. ... But it would be nice to see them overnight, brush their teeth, put them to bed. It would be nice to sort of wake up and know they're in the house.

Second, these fathers described their former partners in ways that reflected the good mother ideal. They and the mothers were child-centered, even when they disagreed about specific issues. Bob was in mediation with his former partner to increase contact with his children, but he described her mothering as child-centered:

I've never had any doubt about [former partner]'s ability as a mother or as a parent or as a responsible human being. ... She'd always do the very best thing for them so I've never had a problem with that.

Third, the fathers did not experience child support as limiting their control of money, possibly because they defined their former partners as good mothers. Tom and his former partner avoided CSA oversight through a private agreement, with each parent responsive to the other's circumstances:

Although I think there was a bit of time when I did struggle a little bit with cash ... [son]'s mum was supportive of that, though, inasmuch as she didn't want to see me go broke either. But, basically, I paid as much as I could afford to pay.

These three fathers presented accounts of the payment and use of child support that de-gendered money. They did not define child support as special money and did not claim authority to judge the legitimacy of mothers' spending decisions and their conformity to feminine and mothering 
ideals. Their interpretation diverged from the connection between money and authority evident in hegemonic masculinity and its expression in the fathering identities of the majority of men in the study. For most men, defining child support as special money de-gendered care through claiming equivalence in the practices and costs of mothers' and fathers' care. For the minority, care was discussed with reference to mothers' and fathers' shared child-centered orientation rather than its financial value.

\section{Mothers' Descriptions of Child-Centered Uses of Child Support}

All mothers in the study described spending child support in ways that benefitted their children. In so doing they emphasized the child-centered care and nurturing central to socially valued femininities enacted in good mothering. Sandra (1 child; annual income $\$ 60,000$; annual child support received \$336) explained: "I think you have this thing that this is money coming for them ... this is actually not for me, this is for them." Mothers' ability to earmark child support for spending directly on their children was shaped by the necessity of that money for the financial stability of their household, and the regularity of payments. Regardless of whether they earmarked child support or incorporated it into the household budget, mothers emphasized their care work.

Earmarking money was related to mothers' ability to meet household costs, rather than income levels. Penny's (3 children; annual income \$30,000; annual child support received $\$ 4,420$ ) income placed her below the poverty line, but she could make ends meet, and earmarked child support for spending on her sons: "That money goes to the boys. They love their sport, there's always a new pair of shoes or registration that's needed. That money goes to them." Cynthia's (3 children; annual income $\$ 49,000$; annual child support received $\$ 39,520$ ) income 
placed her slightly below the Australian median income, and she was also able to earmark child support to child-specific costs:

The first thing I do when I get the child support is I set aside an amount for the school fees. That is the whole focus, really. It's paying the school fees, it is paying for care, it's paying for clothes.

Mothers like Cynthia and Penny earmarked child support for uses that directly and visibly contributed to their children's quality of life. Their differentiation of money suggests its “specialness" (Zelzier 1994), and their spending practices reflected those of child-centered good mothers (Hays 1996; Pugh 2009).

Mothers who collected irregular payments also earmarked child support. They could not rely on its regularity or its use for recurrent expenses, so the money was spent on occasional child-centered costs. Tina (4 children; annual income $\$ 40,000$; annual child support received $\$ 0$ ), who struggled to make ends meet, recalled how she spent child support on one of the past few occasions she received it:

It bought clothes for the kids; we bought clothes and shoes and all the sort of things they sort of need. Took them out for tea, treated them, the things that we can't usually afford to do.

In common with many other mothers in the study, Tina emphasized her child-centered and responsible use of child support. She described covering children's "needs" before spending the money on "treats." Tina's spending choices also implied her conformity with the cultural expectations of meeting children's needs without spoiling them through overconsumption (Pugh 2009). 
Mothers who had a low household income and struggled to make ends meet did not earmark child support. They described using it as part of the work of caring for their children. Child support was necessary for this work. Vanessa (1 child; annual income $\$ 18,200$; annual child support received $\$ 4,760$ ), in common with other mothers in this situation, used the payments to meet general household needs: "It [child support] is imperative, it does help with bills". Although this was not explicitly child-centered spending, mothers described their choices as part of a suite of practices that aligned with feminine nurturing and the centrality of children's well-being in good mothering ideologies (Hays 1996). Vanessa presented her use of child support as part of the ongoing advocacy, planning, and daily care by which she maximized her disabled son's well-being. Similarly, Helen (2 children; annual income \$24,700; annual child support received $\$ 1,040$ ) spent child support on groceries, a particularly large expense due to her children's multiple food allergies. These mothers did not justify their failure to earmark child support for child-specific costs. They described using it in the management of limited money, time, and other resources that was part of the necessary labor of caring for their children on a low and sometimes unstable income.

Irrespective of a household's finances, mothers viewed regular child support as a resource that lessened, or potentially lessened, the challenges and complexities of money work that was part of child-centered care. This attitude is expressed in Tina's description of what it would be like if she received regular child support:

You wouldn't be thinking, "Well, okay, how much can I spend this fortnight on food, and can I afford to go and lay-by the kids those clothes that they need?" You would know, "Yes, I can do that and I can do that." You know, you don't have to think, "What will I do here?" 
Mothers with more financial resources did not describe child support as essential, but they acknowledged it was useful in meeting the needs and interests of their children. Emily (4 children; annual income $\$ 40,000$; annual child support received $\$ 7,200$ ) described herself as “...very lucky financially in that I am working and we got a reasonable amount from our other house so I don't have a huge mortgage.” In this context, Emily still saw child support as “important because it enables me to send them to tennis lessons ... you could survive without it, but it just makes all our lives a bit better, I think." Through their accounts of spending child support the mothers presented themselves as autonomous decision makers. They determined the use of child support and were not dependent on it or the former partners who paid - and did not pay - the money. Their spending diverged from the dependency that is an important element of socially valued femininities in family contexts (Fraser and Gordon 1994).

Belinda’s (1 child; annual income $\$ 38,000$; annual child support received $\$ 7,930$ ) comments highlighted an alternative interpretation of child support's importance. She understood child support as an acknowledgment of the indirect costs and foregone opportunities that were the consequences of her conformity to feminine and good mother ideals:

It is hard, actually, and I have always chosen to work casually and part-time. I didn't want to work full-time because she was my priority and so I have remained poor. ... I think that it [child support] is more important [than other sources of money], because it is also recognition from your ex-partner that you are really in the sole care of that person. ... I have been responsible for all of her costs and I have often wondered, I don't think the maintenance I have received will cover all of her financial needs; I don't know, really, but I don't think so. 
The use of child support as special money was not available to all mothers. Irrespective of their decision to earmark child support or incorporate it into the household budget, mothers emphasized their child-centered spending and care work in ways that reproduced socially valued femininities and good mothering. Other dimensions of femininity were adjusted: Mothers presented themselves as autonomous decision makers and not dependent on their former partners. This partially reflects the absolute and relative contributions of child support to household budgets and income from paid employment and state transfers, and also suggests the existence of alternative enactment of the relationship between femininity and money.

\section{CONCLUSION}

The ways in which men and women talked about appropriate uses of child support suggested a consensus that child support was to be spent for the benefit of children. This agreement should not be overstated. Fathers most commonly aligned money spent for children with money spent explicitly and directly on children, but there were differences, with a minority not defining child support as special money in this way. There were diverse accounts of spending priorities and practices among mothers, reflecting different levels of household income and regularity of child support receipt. Child support was not only a resource to meet children's needs - when people discussed how child support was or should be spent they were enacting and contesting gendered parenting identities.

By paying child support fathers displayed their commitment to their children and managed their identities as men. In some contexts, elements of hegemonic masculinity were challenged. Fathers used the "specialness" of child support to justify calculations of the marginal costs of children, which in turn informed their claims of equivalence between mothers' 
and fathers' contributions to their children's care. Previous work has shown how care of children reproduces and challenges hegemonic masculinity through practices that differentiate masculine and feminine care within families (Edin and Nelson 2013; Randles 2013; Shows and Gerstel 2009). In our study, men explicitly and implicitly presented their care contributions as the same as, or similar to, those of their former partner. Their descriptions suggest a discursive undoing of gender (Deutsch 2007) in the care of children in post-separation relationships, so that care was an expression of parenting rather than of masculinities or femininities.

Simultaneously, money and care were used by most fathers to reinforce hegemonic masculinity and socially valued femininities in ways that highlight the relational character of the gender order (Connell and Messerschmidt 2005). We suggest fathers' evaluations were linked to frustrations over mothers' situational authority (Smart and Neale 1999) that undermined masculine control. In response to this frustration, fathers used their masculine authority to position themselves as legitimate judges of their former partners' femininity and mothering. When using a child-specific marginal costs approach to the cost of children, fathers contrasted their child-centered definition of child support as special money with mothers' presumed selfinterest and inappropriate spending. Fathers appropriated expectations of child-centered care, an element of socially valued femininities, to claim good fathering and represent their former partners as bad mothers.

Three fathers offered an alternative definition of the legitimate use of child support and a different relationship between care, money, and fathering. Unlike the majority of fathers, they did not link the amount of care they provided with the amount of child support they should pay, and they did not directly compare the quality and quantity of their child-centered care with that of mothers. Nor did they draw on masculine authority when managing their relationships with 
their former partners, but suggested parenting was a shared endeavor. We cannot draw any conclusions about a widespread adjustment of hegemonic ideals in the context of post-separation fathering; however, these three fathers suggest the possibility of a post-separation masculinity enacted through the provision of care and money, but de-coupled from masculine authority. Research designed to identify the contexts and interactions that facilitate transformative masculinities in post-separation contexts would be useful to build on this finding.

Mothers' accounts of spending child support reflected the feminine ideals of nurturing and child-centered mothering (Hays 1996; Ruddick 1989). They acknowledged the importance of child support - and particularly child support that was regularly paid - in meeting a range of expenses that accrued from raising their children. The men in this study, in common with fathers' rights groups (Crowley 2008), dichotomized spending child support on self versus spending on children as the competing priorities facing mothers. For mothers managing on low incomes, the two were often combined as child support was incorporated into their budgets and used for household expenses like rent or groceries. For many mothers in this study, the importance of child support lay less in its contribution to the specific costs of children and more as a resource that increased their ability to manage the care work and money work by which they raised their children. Their accounts highlighted their authority over their financial choices, and they did not explain their choices with reference to a former partner's expectations about how child support would be spent. Their control of money suggested the absence of subordination at the local level (Connell and Messerschmidt 2005).

Our study analyzes practices of hegemonic masculinity and socially valued femininity at the local level, but given the relationship between local and regional masculinities (Connell and Messerschmidt (2005), it also speaks to the relationships of domination and subordination that 
constitute the gender order (Connell and Messerschmidt 2005). When fathers used a marginal costs approach to calculate the costs of children and applied this to judge the legitimacy of their child support obligations and mothers' spending, they elided the work that is part of mothering even as they emphasized the care that is central to socially valued femininities. There has been some exploration of the invisibility and appropriation of mothers' care labor in separated families (Elizabeth, Gavey, and Tolmie 2012b; Lacroix 2006); our analysis extends this work by suggesting that the same processes apply to fathers' understandings of mothers' financial contributions and "money work." Separated mothers, particularly those with low incomes, pursue often complex and demanding strategies to achieve oftentimes precarious financial stability and meet their children's needs, including planning, generating, budgeting, spending, and saving money (Edin and Lein 1997; McCormack 2005). When mothers are responsible for this money work, fathers may accrue the time, money, and social and emotional benefits of not having to manage money to meet the daily needs of their children. In the absence of structural and cultural change fathers' discursive undoing of gendered care reinforces the patriarchal dividend (Connell 1995).

Within the logic of many welfare states, child support is an important element of good fathering because it positions men as financial contributors to their children's needs, thereby limiting mothers' reliance on state transfers (Curran and Abrams 2000). Randles (2013) has highlighted the state's support of low-income, non-married men's care with the aim of achieving this same end. There is a simultaneous cultural and political privileging of rhetoric that single mothers are fiscally irresponsible, selfishly spending "others" money (the state's welfare transfers, former partners' child support payments) on luxuries for themselves rather than necessities for their children (Crowley 2008; McCormack 2005). 
In this context, the benefits of engaged fathering as they are promoted through policy and political claims can exist in tension with women's financial autonomy and legitimacy as mothers. For most fathers in this study, contributing child support was only part of fathering: retaining control by "having a say" over how mothers spent "my" money enabled men to father in ways that aligned with and reproduced hegemonic masculinity. When these claims are incorporated into policy or law, they institutionalize domination and subordination by reinforcing hegemonic masculine control over money and compelling traditional feminine subservience to men's interests and financial authority. At a material level, mothers may be directed by fathers to spend child support on costs they did not choose and cannot afford in the context of strained budgets. Thus, already poor mothers may experience further economic and social vulnerability. Connell and Messerschmidt (2005) remind us that challenges to hegemonic masculinity have the potential to undo gender hierarchy but, in the context of paying and using child support, this undoing has not yet eventuated. 


\section{REFERENCES}

Australian Bureau of Statistics. 2008. Year book Australia, 2008 (Vol. Cat.1301.0).

Canberra: Australian Bureau of Statistics.

Australian Bureau of Statistics. 2011. Family characteristics, Australia 2009-10 (Vol. Cat. 4442.0). Canberra: Australian Bureau of Statistics

Australian Bureau of Statistics. 2012. Births, Australia. (Vol. Cat. No. 3301.0). Canberra: Australian Bureau of Statistics.

Australian Bureau of Statistics. 2013. Gender indicators, Australia. (Vol. Cat. No. 4125.0). Canberra: Australian Bureau of Statistics.

Birks, K. Stuart. 2011. An assessment of proposed changes to the child support formula. Policy Quarterly 7: 31-38.

Boyd, Susan B. 2003. Walking the line: Canada's response to child custody law reform discourses. Canadian Family Law Quarterly 21: 397-423.

Bradshaw, Jonathan, Carol Stimson, Christine Skinner, and Julie Williams. (1999). Absent fathers? London: Routledge.

Cancian, Maria and Daniel Meyer. 2005. Child support in the United States: An uncertain and irregular income source? Institute of Research on Poverty 1298-05.

Casey, Emma. 2003. Gambling and consumption. Journal of Consumer Culture 3: 245-63. Child Support Agency. 2010. Facts and figures 2008-09. Belconnen, ACT: Child Support Agency.

Child Support Agency. 2011. CSA: Supporting parents to meet their child support responsibilities: 2010-2012 compliance program. Canberra: Department of Human Services. Christopher, Karen. 2012. Extensive mothering: Employed mothers' constructions of the good mother. Gender \& Society 26: 73-96. 
Collins, Patricia Hill. 2000. Black feminist thought: Knowledge, consciousness, and the politics of empowerment, 2nd ed.. New York: Routledge

Connell, Raewyn. 1995. Masculinities. Cambridge, UK: Polity Press.

Connell, Raewyn and James W. Messerschmidt. 2005. Hegemonic masculinity: Rethinking the concept. Gender \& Society 19: 829-59.

Cook, Kay and Kristin Natalier. 2013. The gendered framing of Australia's child support reforms. International Journal of Law, Policy and the Family 27: 28-50.

Crowley, Jocelyn. 2008. Defiant dads: Fathers' rights activists in America. Ithaca, NY:

Cornell University Press.

Curran, Laura and Laura Abrams. 2000. Making men into dads: Fatherhood, the state, and welfare reform. Gender \& Society 14: 662-78.

Deutsch, Francine. 2007. Undoing gender. Gender \& Society 21: 106-27.

Devault, Marjorie L. 1991. Feeding the family. The social organization of caring as gendered work. Chicago and London: University of Chicago Press.

Edin, Kathryn and Laura Lein. 1997. Making ends meet: How single mothers survive welfare and low wage work. New York: Russell Sage Foundation.

Edin, Kathryn and Timothy J. Nelson. 2013. Doing the best I can: Fatherhood in the inner city. Berkeley and Los Angeles: University of California Press

Elizabeth, Vivienne, Nicola Gavey, and Julia Tolmie. 2012a. The gendered dynamics of power in disputes over the post-separation care of children. Violence Against Women 18: 45981.

Elizabeth, Vivienne, Nicola Gavey, and Julia Tolmie. 2012b. “...He’s just swapped his fists for the system": The governance of gender through custody law. Gender \& Society 26: 23960. 
Ellman, Ira M. 2004. Fudging failure: The economic analysis used to construct child support guidelines. University of Chicago Legal Forum 167: 167-224.

Fehlberg, Belinda and Juliet Behrens. 2008. Australian family law: The contemporary context. Melbourne: Oxford University Press.

Fehlberg, Belinda and Mavis Maclean. 2009. Child support policy in Australia and the United Kingdom: Changing priorities but a similar tough deal for children? International Journal of Law, Policy and the Family 23: 1-24.

Fraser, Nancy and Linda Gordon. 1994. A genealogy of dependency: Tracing a keyword of the U.S. welfare state. Signs: A Journal of Women in Culture and Society 19: 309-61. Gavanas, Anna. 2004. Domesticating masculinity and masculinizing domesticity in contemporary U.S. fatherhood politics. Social Politics: International Studies in Gender, State and Society 11: 247-66.

Hays, Sharon. 1996. The cultural contradictions of motherhood. New Haven, CT: Yale University Press.

Johnson, Allan G. 2005. The gender knot: Unraveling our patriarchal legacy. Philadelphia: Temple University Press.

Johnston, Deirdre and Debra Swanson. 2006. Constructing the "good mother": The experience of mothering ideologies by work status. Sex Roles 54: 509-19.

Kenney, Catherine T. 2006. The power of the purse: Allocative systems and inequality in couple households. Gender \& Society 20: 354-81.

Lacroix, Carol. 2006. Freedom, desire and power: Gender processes and presumptions of shared care and responsibility after parental separation. Women's Studies International Forum 29:184-196.

McCormack, Karen. 2005. Stratified reproduction and poor women's resistance. Gender \& Society 19: 660-79. 
Natalier, Kristin. 2012a. Descriptions of loss and resilience among fathers paying child support. Journal of Family Studies 18: 242-51.

Natalier, Kristin. 2012b. Means and ends: Why child support money is not used to meet housing costs. Housing Studies 27: 174-88.

Natalier, Kristin and Belinda Hewitt. 2010. "It's not just about the money": Non-resident fathers' perspectives on paying child support. Sociology 44: 489-505.

Natalier, Kristin, Maggie Walter, Maryann Wulff, Margaret Reynolds, and Belinda Hewitt. 2008. Child support and housing outcomes: Final report. Melbourne: Australian Housing and Urban Research Institute.

Patrick, Rebecca, Kay Cook, and Hayley McKenzie. 2008. Domestic violence and the exemption from seeking child support: Providing safety or legitimating ongoing poverty and fear? Social Policy and Administration 42: 749-67.

Pugh, Allison. 2009. Longing and belonging: Parents, children and consumer culture. Berkeley: University of California Press.

Randles, Jennifer M. 2013. Repackaging the "package deal": Promoting marriage for lowincome families by targeting paternal identity and reframing marital masculinity. Gender \& Society 27: 864-88.

Rice, Pranee and Douglas Ezzy. 1999. Qualitative research methods: A health focus. Melbourne: Oxford University Press.

Ruddick, Sara. 1989. Maternal thinking. Boston: Beacon Press.

Shows, Carla and Naomi Gerstel. 2009. Fathering, class, and gender: A comparison of physicians and emergency medical technicians. Gender \& Society 23: 161-87.

Silverman, David. 2001. Interpreting qualitative data : Methods for analysing talk, text, and interaction. London; Thousand Oaks, CA: Sage. 
Simpson, Bob. 1998. Changing families: An ethnographic approach to divorce and separation. Oxford; New York: Berg.

Skinner, Christine and Jacqueline Davidson. 2009. Recent trends in child maintenance schemes in 14 countries. International Journal of Law, Policy and the Family 23: 25-52. Skinner, Christine and Gill Main. 2013. The contribution of child maintenance payments to the income packages of lone mothers. Journal of Poverty and Social Justice 21: 47-60. Smart, Carol and Bren Neale. 1999. Family fragments? Cambridge, UK: Polity Press. Smyth, Bruce and Paul Henman. 2010. The distributional and financial impacts of the new Australian child support scheme: A "before and day-after reform" comparison of assessed liability. Journal of Family Studies 16: 5-32.

Summerfield, Tracey, Lisa Young, Jade Harman, and Paul Flatau. 2010. Child support and welfare to work reforms: The economic consequences for single parent families. Family Matters 84: 68-78.

Volger, Carolyn, Clare Lyonette, and Richard Wiggins. 2008. Money, power and spending decisions in intimate relationships. The Sociological Review 56: 117-43.

Weiss, Jessica. 2000. To have and to hold: Marriage, the Baby Boom and social change. Chicago: University of Chicago Press.

Zelizer, Viviana. 1994. The social meaning of money. New York: Harper Collins. 